\title{
Incremental processing of polymer materials using the INDUSTRY 4.0 network structure
}

\author{
Andrzej Paszkiewicz') (ORCID ID: 0000-0001-7573-3856), Grzegorz Budzik ${ }^{2)}$ (0000-0003-3598-2860), \\ Marek Bolanowski ${ }^{1)}$ (0000-0003-4645-967X), Joanna Woźniak ${ }^{3), *)}$ (0000-0002-3186-6347), Mateusz Przytuła), \\ Mateusz Kiełbicki ${ }^{4)}$, Przemysław Poliński ${ }^{4)}$, Lukasz Kochmański ${ }^{2)}$
}

DOI: dx.doi.org/10.14314/polimery.2021.7.5

\begin{abstract}
The article presents the possibility of polymeric materials incremental processing, using the network structure of INDUSTRY 4.0. The selected network control systems for 3D printers processing polymer materials were analyzed in terms of software and hardware identification used in industrial conditions, science and education. Both solutions requiring continuous data exchange between the controlling computer and the 3D printer and systems dedicated to control with the use of a computer network were taken into account. The possibilities of adapting 3D printers to work in the remote control mode and control of the incremental process are presented. The possibilities of developing processes related to 3D printing based on remote control using network systems were also determined.
\end{abstract}

Keywords: polymer materials, network communications, 3D printing, additive manufacturing.

\section{Przyrostowe przetwarzanie materiałów polimerowych z zastosowaniem sieciowej struktury INDUSTRY 4.0}

Streszczenie: Artykuł przedstawia możliwości przyrostowego przetwarzania materiałów polimerowych z zastosowaniem sieciowej struktury INDUSTRY 4.0. Analizie poddano wybrane systemy sterowania sieciowego dla drukarek 3D pod względem identyfikacji softwarowej i hardwarowej stosowane $\mathrm{w}$ warunkach przemysłowych, nauce i edukacji. Wzięto pod uwagę zarówno rozwiązania w których występuje konieczność ciągłej wymiany danych pomiędzy komputerem sterującym a drukarką 3D oraz systemy, które są dedykowane do sterowania z zastosowaniem sieci komputerowej. Przedstawiono możliwości adaptacji drukarek 3D do pracy w trybie zdalnego sterowania i kontroli procesu przyrostowego. Określono również możliwości rozwoju procesów związanych z drukiem 3D w oparciu o zdalne sterowanie wykorzystujące systemy sieciowe.

Słowa kluczowe: materiały polimerowe, komunikacja sieciowa, druk 3D, technologie przyrostowe.

The development of additive manufacturing technology began with the processing of polymer materials, which also constitute the majority of currently processed materials using 3D printing methods. These types of manufacturing processes are associated with the need

\footnotetext{
1) Rzeszow University of Technology, The Faculty of Electrical and Computer Engineering, al. Powstańców Warszawy 12, 35959 Rzeszów, Poland.

2) Rzeszow University of Technology, Faculty of Mechanical Engineering and Aeronautics, Department od Mechanical Engineering, al. Powstańców Warszawy 12, 35-959 Rzeszów, Poland.

3) Rzeszow University of Technology, Faculty of Management, al. Powstańców Warszawy 12, 35-959 Rzeszów, Poland.

4) Doctoral School of Engineering and Technical Sciences at the Rzeszow University of Technology, al. Powstańców Warszawy 12, 35-959 Rzeszów, Poland.

*) Author for correspondence: j.wozniak@prz.edu.pl
}

to implement them into a modern production structure based on the Industry 4.0 concept [1,2]. The assumptions of this concept are related to the automation and computerization of the design, production and delivery of finished products and individual components integration requires facing many technological challenges [3,4]. As rightly stated by J. Patalas-Maliszewska and M. Topczak, Industry 4.0 introduces leading-edge IT solutions in all aspects of manufacturing, and striving to achieve the right level of digital. The analysis is carried out for various areas of such integration, i.e. at the level of business or technological processes, but also in relation to the application layer or communication [5]. K. Schwab, analyzing the leading technologies characteristic of the fourth industrial revolution, points out that it is important to always carry out a comparison of opportunities and risks associated with the implementation of specific solutions [6]. This opinion seems justified. As the research shows, there is a growing knowledge among 
entrepreneurs about the very concept of Industry 4.0 and the management is aware of the benefits and risks resulting from it [7].

Given the pace of digitization and incremental technologies, it is therefore worthwhile to analyze the network control capabilities for printers that are part of a virtual production network or that operate as part of R\&D work. In this context, a gap in research has been observed in terms of presenting how 3D printers can be adapted to operate in remote control mode as well as to control the incremental process. Therefore, the main objective of this paper is to analyze the current possibilities and future potential for attaching 3D printers processing polymeric materials to computer networks. Network integration of these devices provides an ongoing and permanent monitoring and control devices for both themselves and the process of printing. As a result of such activities, it is possible to reduce costs and increase efficiency, availability, and shorten the design and production time. It is associated with providing remote access to devices, ongoing supervision over the correctness of the manufacturing process, but also with the schedule optimization for the implementation of individual works. In order to ensure an appropriate network integration level, two levels of hardware and software should be considered. The first one relates to the available methods and means of ensuring network communication, while the second is related to application support. These two levels are inextricably linked and must be mutually developed and perceived as one coherent IT system. Considering the range of challenges faced by engineers creating solutions for Industry 4.0, this task is very difficult and requires finding a com- promise between user expectations, technological limitations, industry standards, as well as reliability, security, scalability and interoperability. In addition to these issues, there is also the dispersed nature of production resources, which is characteristic of modern industry $[8,9]$. Limited resources necessitate establishing of cooperation between various entities and organizations from the science and industry. Therefore, in order to increase the efficiency of the design and production capacities use, adequate network tools are required.

As part of the research and development work at the Rapid Prototyping Laboratory at the Rzeszów University of Technology, a heterogeneous design and manufacturing environment dedicated to additive manufacturing systems based on polymer materials has been created for many years. Only access to various 3D printing platforms makes it possible to use the potential of various technologies. Therefore, as part of this publication, an analysis of the network integration possibilities of solutions dedicated to 3D printing was undertaken, also in the potential adaptation of already existing systems field.

\section{ANALYSIS OF NETWORK SOLUTIONS OF 3D PRINTERS FOR POLYMER MATERIALS}

The incremental devices processing polymeric materials are equipped with various communication solutions allowing data processing for the manufacturing process. There are 3D printers with a direct connection to the control computer, printers with network connections (LAN), printers with a wireless Wi-Fi network connection, printers with memory card readers, and printers with vari-

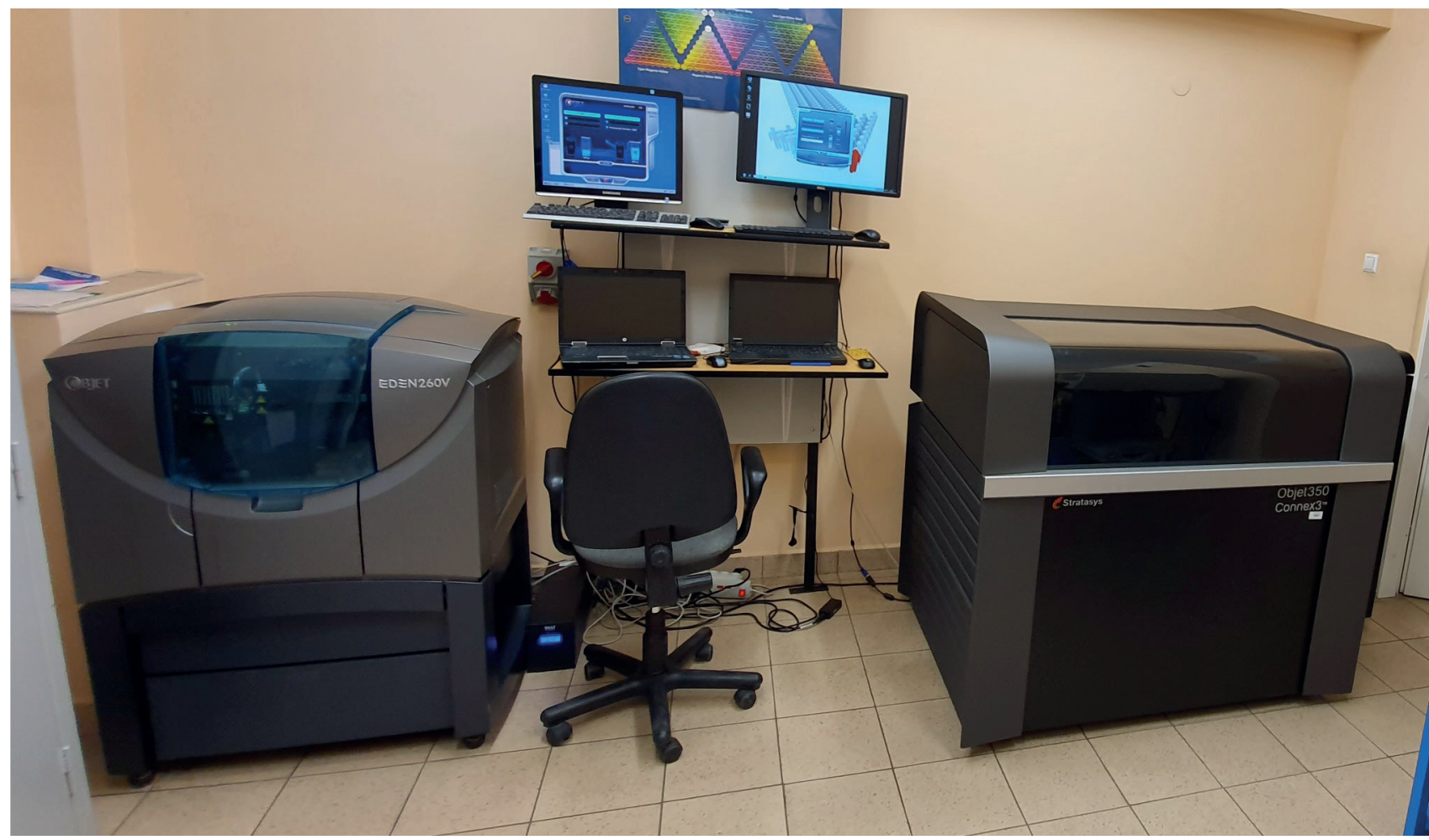

Fig. 1. Objet Eden 260 and Objet 350 Connex 3 3D printers connected to the control computers by the network 
ous data transfer systems, as standard equipment or for modification by the user [10].

The selected devices for 3D printing, which are the the Department of Mechanical Engineering eqipment, which constitute a representative cross-section of additive technologies currently available on the market, were analyzed.

Machines for 3D printing with photopolymers based on PolyJet technology are most often equipped with LAN network interfaces, where the printer can be connected directly to a computer or used as a network printer. Fig. 1 shows the Objet Eden 260 and Objet 350 Connex 3 3D printers connected to the control computers by network.

The data for the incremental process is sent from the computer over a LAN-type network link. It is necessary to connect the computer permanently to the printer during the process, because the data are transferred in stages as the construction of subsequent layers.

Devices working in the technology of thermoplastic polymers layer extrusion have various communication solutions. Industrial printers using FDM technology by Stratasys are equipped with a LAN connection and USB inputs (next to the control panel - Fig. 2a), through which data can be entered (data), to be printed only using the data carriers supplied with the machine. The device can also be connected to a wired network and process data can be transferred in this way. PRUSA brand desktop 3D printers are equipped as standard with an SD memory card slot, which is used for data entry. However, it is possible to extend the printer with an additional module for connecting it to a wireless network. Fig. $2 \mathrm{~b}$ shows a set of two printers equipped with WiFi modules connected to the internal network. Additionally, cameras connected to the network are built into the structure integrating 3D printers. This set enables visual preview of the process using cameras and program preview using Octoprint software [11]. The Ultimaker device (Fig. 2c) is equipped with a USB input for data transfer from storage media, WiFi and LAN connection (on the back of the printer). In addition, the printer has a built-in camera with which the printing process can be monitored.

\section{DEVELOPMENT OF NETWORK COMMUNICATION IN 3D PRINTING SYSTEMS}

Additive technologies are used in many areas of science, as well as in various sectors of the economy, such as aviation [12-14], automotive [15, 16], electromechanical [17, 18], constructional [19-21], medical [22-24]. They are used both for multi-series production as well as in short series, or for the production of individual elements used, for example, in the construction of prototypes or a)

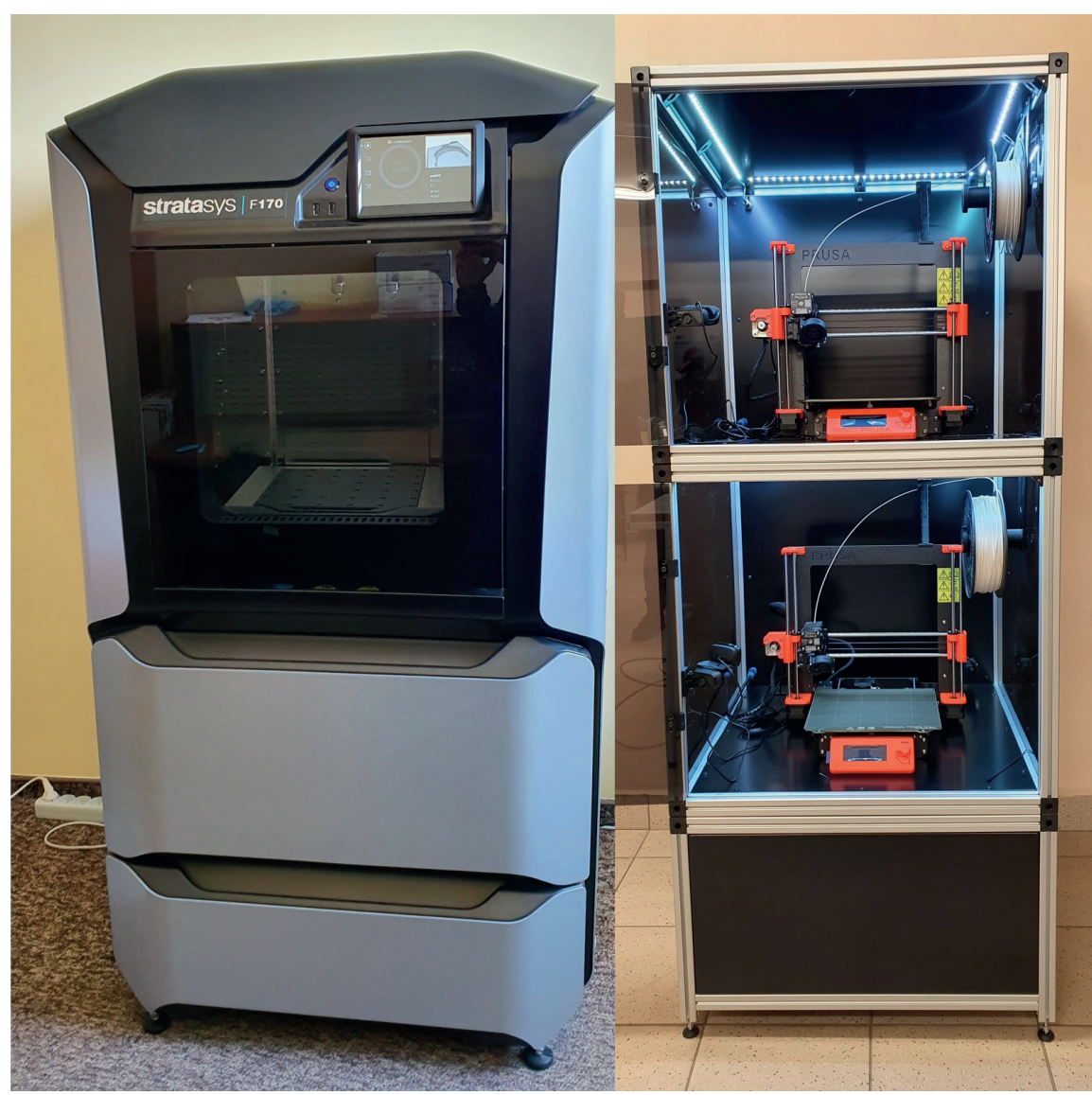

c)

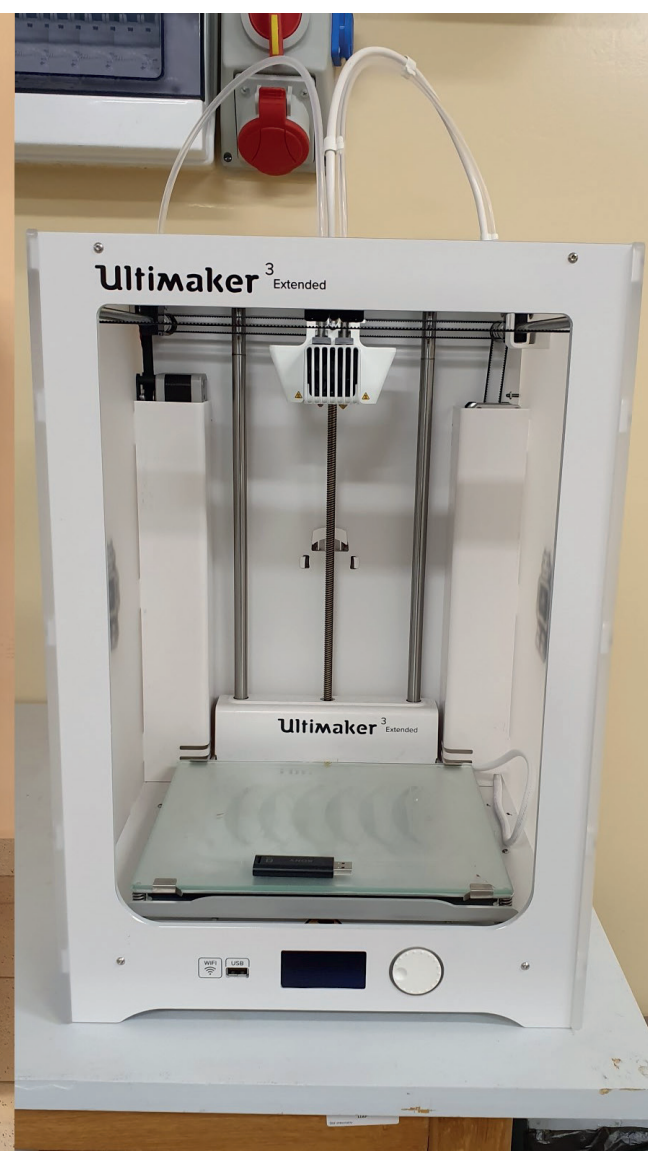

Fig. 2. Devices working in the technology of layer extrusion of thermoplastic polymers: a) Stratasys F170 printer, b) a set of integrated Prusa printers, c) Utlimaker printer 

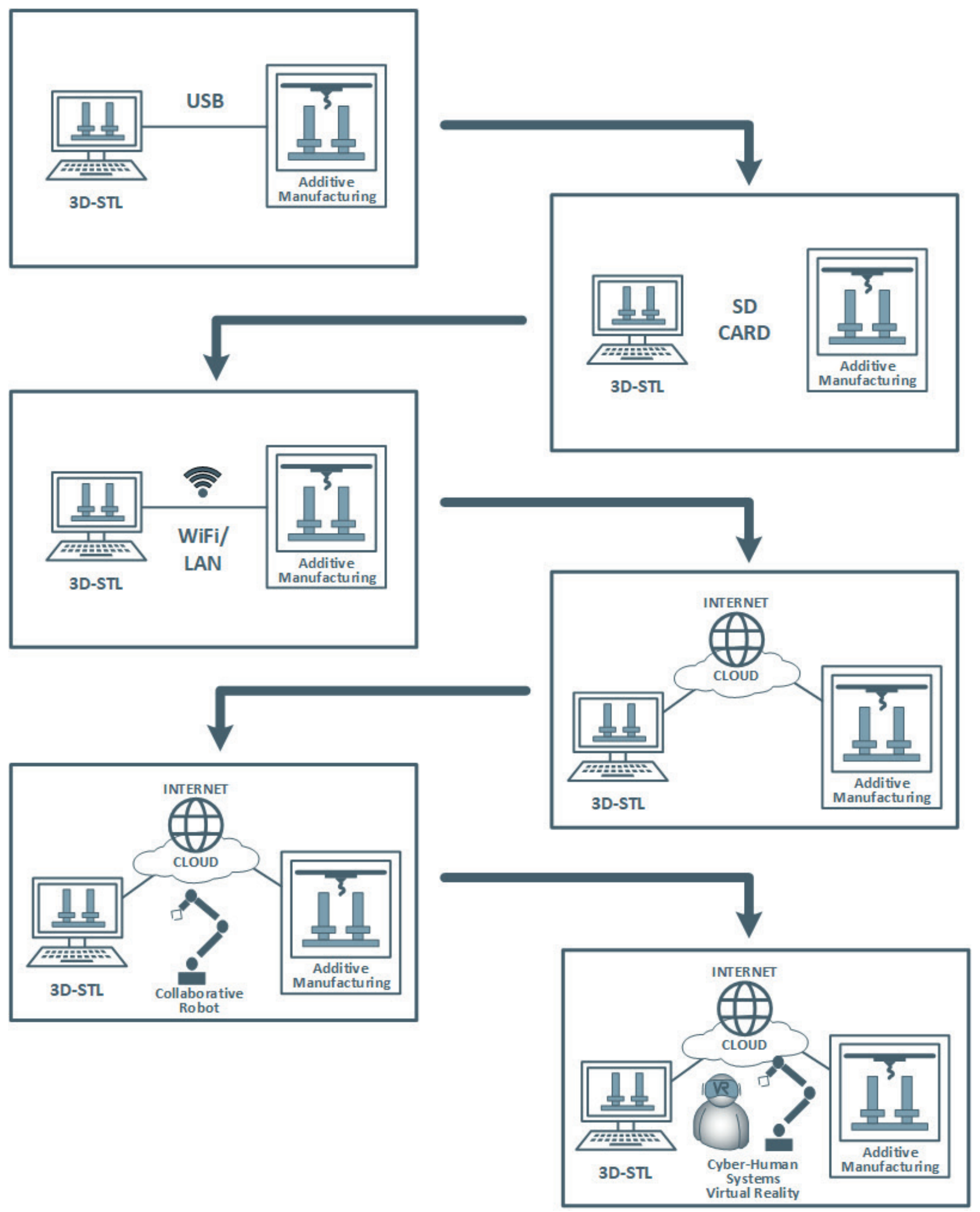

Fig. 3. Evolution of information exchange systems between information and production systems. 
customized for the needs of a given customer [25]. These technologies have been developed for about 50 years. For a long time, the main focus was on the new types of polymer materials developmemt and composites that could be used in 3D printers [26], as well as the efficiency and effectiveness of manufacturing processes [27]. Work in this area is still carried out in order to obtain solutions with new properties and that could revolutionize, for example, repairs made in space [28]. Nevertheless, with the advent of the fourth industrial revolution, communication and data exchange became a key issue. Thus, the implementation of the Industry 4.0 concept would not be possible without the strict integration of production systems with IT systems [6]. The evolution of this process over several decades is presented in Fig. 3.

Only the stage in which manufacturers of printing devices began to implement LAN and WiFi network interfaces allowed full remote control and control of devices and the printing process. It can be concluded that the moment of universal access to the computer network, and in particular the Internet, was one of the fourth industrial revolution and the wider development of the Internet of Things (IoT) foundations. Thanks to this, an opportunity appeared, and a new trend of remote work emerged [6, 11, 29]. Significant moment for the development of communication support systems for solutions based on incremental technologies was the emergence of cloud computing. These technologies have revolutionized many areas of our life [30-32], and thus also influenced the area related to 3D printing. Resource virtualization ensured scalability of design and manufacturing systems, and thus it was possible to increase the efficiency of use, reduce costs and extend cooperation in both $\mathrm{B} 2 \mathrm{~B}$ and $\mathrm{B} 2 \mathrm{C}$ relations $[9,33-35]$. We are currently at the stage of this type of systems, where people are gradually replacing people with robots controlled by IT systems. Thanks to this, it is possible to use the available data from business systems, queuing and supervising tasks, warehouse and logistics systems, as well as manufacturing systems more widely. Taking into account the virtualization of application resources, including software for modeling and designing components as well as supervision of additive manufacturing processes, we are getting closer to achieving operational efficiency at the level of cyber-physical systems controlled and monitored by computer algorithms. This in turn leads to the realization of a fully functioning Industry 4.0 infrastructure.

\section{NETWORKING OF THE DESIGN AND MANUFACTURING PROCESS IN 3D PRINTING TECHNOLOGY}

The process of designing and manufacturing in 3D printing technology means the rapid prototyping process, which is focused on fast, precise and repeatable production of components using additive technologies. Its individual stages are presented in Fig. 4. Nowadays, specific actions taken as part of this process can be implemented remotely, with the cooperation of people and devices, connected via a computer network. Networking of individual stages in the rapid prototyping process increases the efficiency and scalability of production. We can distinguish two areas within the network structure. The first is the area of people connected to the network, and

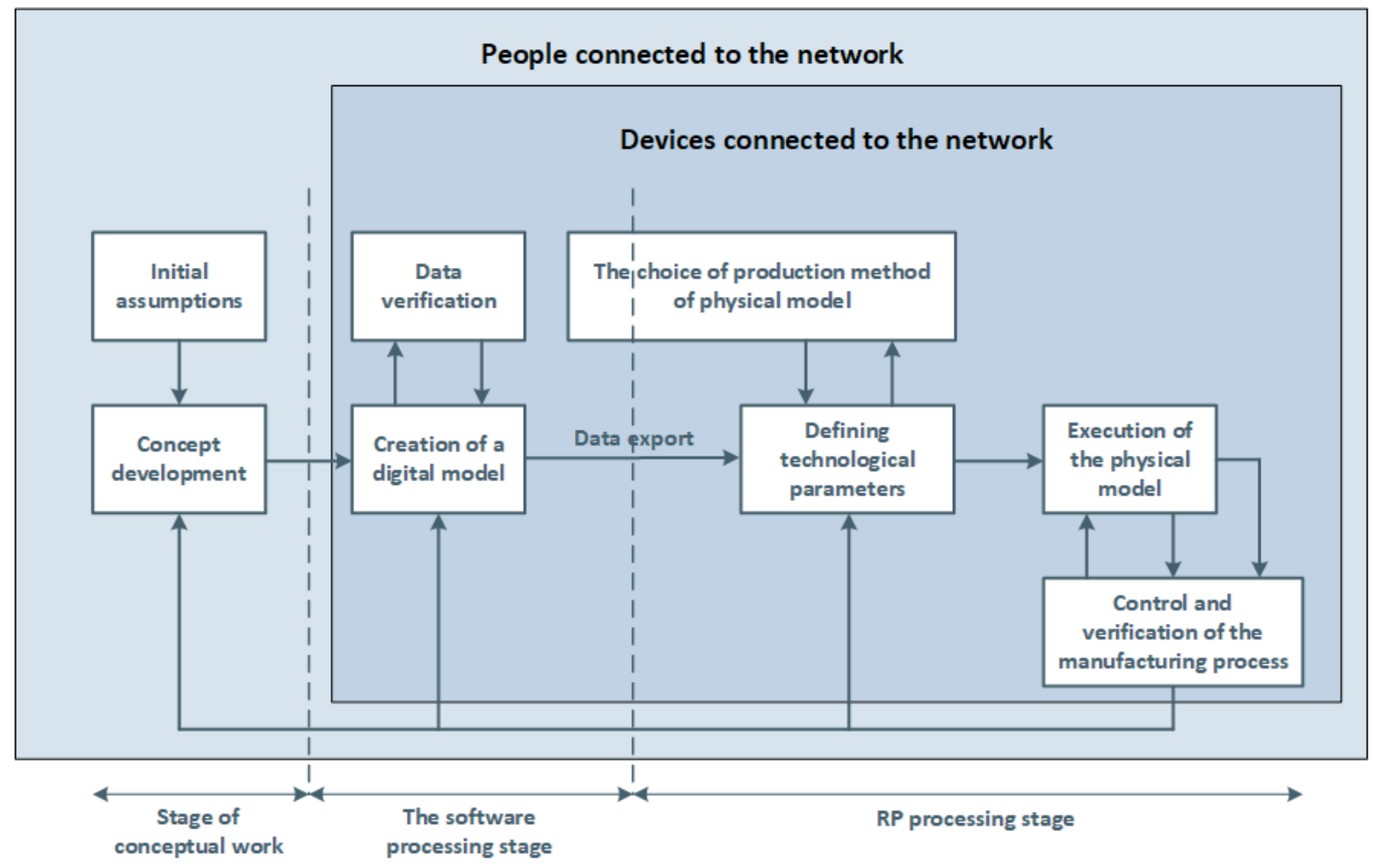

Fig. 4. Networking of the prototyping process 
the second includes devices and applications connected by a computer network that make up the modern Internet of Thing. However, the network integration of both areas allows to get the Internet of Everything.

The initial stages of the rapid prototyping process concern conceptual work and the preparation of initial assumptions for the model of the target component. These activities, of course with the support of modern IT tools, are more and more often carried out remotely with the cooperation of a distributed project team members. The next stages, including the preparation of a 3D model, its verification and conversion to an STL file, transfer of finished models to the printer, printing, as well as verification and control of the resulting component can be carried out with full network integration between devices such as workstations, servers, 3D printers, cameras, 3D scanners, etc. and the staff forming the design and execution team. Based on the initial requirements and assumptions, a 3D digital model is developed in an environment of specialized CAD applications. By sharing resources, it is possible to verify the data and introduce possible corrections to the modeled object jointly. After receiving the digital model, there is a need to export the data in order to prepare the physical process of its production directly. At this point, in the IoT environment, data is transferred between devices via a computer network.

Each of the rapid prototyping process stages, described above, is of significant importance to it and, as you can see, can be implemented through network communication corresponding to the assumptions of the Industry 4.0 concept.

It should be emphasized that network devices such as 3D printers should be considered in terms of IoT elements. The last stages of the evolution of information exchange systems between information systems and production systems should be seen in terms of the Internet of Everything systems (IoE). It should be remembered that in this class of systems a human is an element of the entire infrastructure, which means that a number of new types of threats can be identified for it. For example, during the research, it was possible to effectively gain access to a camera monitoring the printouts of several 3D printers. Due to the lack of updates, the camera software had a number of vulnerabilities that allowed not only to capture the image from the camera, but also to gain access to the camera movement control system. Thanks to this, it was possible to view the strings of characters entered on the keyboard and to read the documents left at the workstation.

\section{PROPOSED SAFETY ARCHITECTURE OF CONTROL SYSTEMS}

Considering these threats authors of the article propose a solution for sharing and control of 3D printing, which allows you to protect the organization intranet resources while allowing remote control of them. The general scheme of the architecture is presented in Fig. 5.

All 3D printers have been placed in a separate segment of the VLAN network, which has disabled the ability to communicate with each other. Only two-way communication with the IDS / IPS / UTM system is possible. Individual printers are connected to the network in the architecture described in chapter 2 . However, the module described in the figure as "External module" (EM) requires a more detailed description. A number of solutions have appeared on the market that allow to manage 3D printers shared by the network. They have simplified interfaces allowing the implementation of basic activities related to print management. To simplify the management of printers, additional external communication modules are offered, which constitute an access interface between the printer usually connected to the USB port and the operator's cloud. As a rule, solutions of this class are designed to support the production resources of a single entity. The most popular are: FlexiHub (software solution) [36], USB Network Gate (software solution), USB over Network (software solution) [37], Floow2.

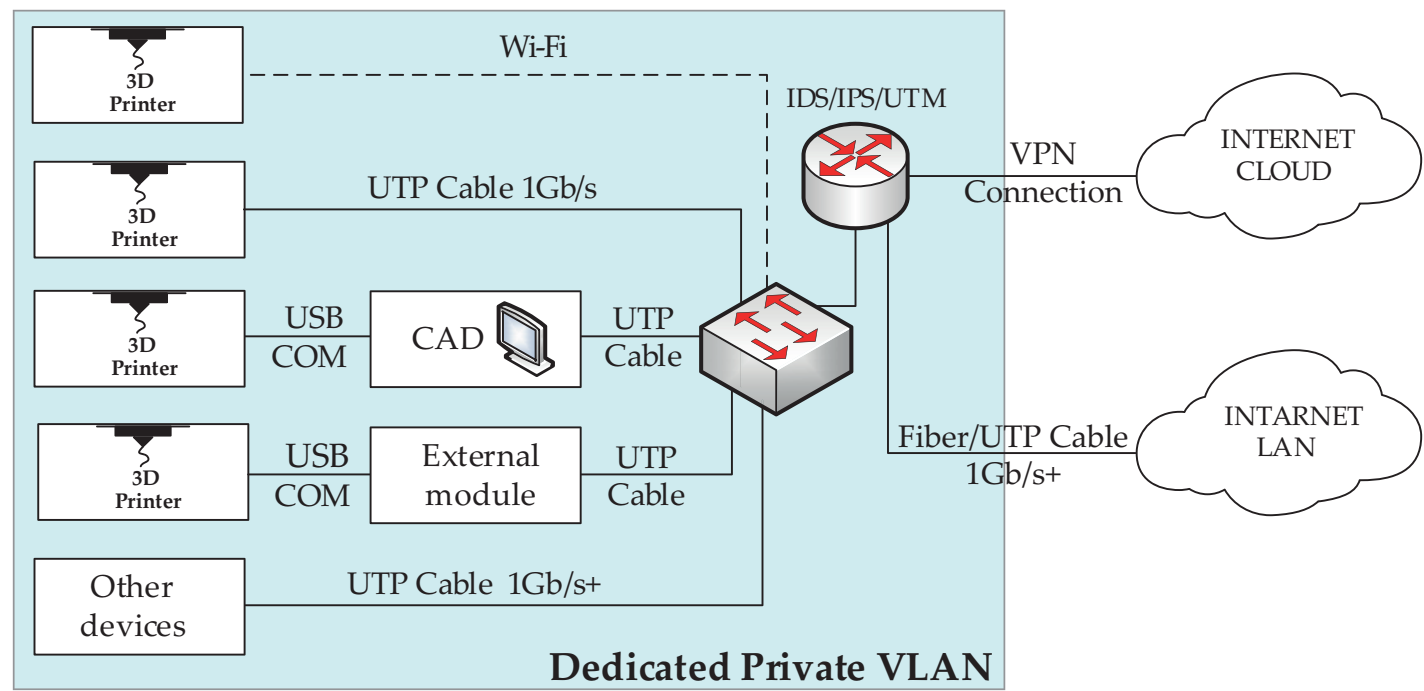

Fig. 5. The architecture of printer system control 
com (comprehensive hardware and software solution) [38], 3DPrinterOS (hardware and software solution) [39], OctoPrint + Raspberry Pi (hardware / software solution) [40]. It si important be aware that the introduction of an EM network module managed by an external organization may not be compliant with the policy of the company providing resources and with the applicable security rules. Therefore, separating the resource made available in this way from the rest of the network allows to minimize the losses resulting from the possible compromise of the EM device. This also applies to printers shared and controlled by any of the other methods described in this article. The entire system is protected by the IPS / IDS / UTM access control system, which is also responsible for compiling encrypted communication channels to cloud resources or cooperating companies. It is the main point of system protection, which can be integrated with Security Event Manager systems that supervise the system as a whole. The proposed architecture also enables the integration of the system with dedicated management automation systems with the use of an arbitrator [41], or for the detection of anomalies [42]. Access to 3D printers from the intranet network, as in the case of extranet systems, is carried out via the IDS / IPS / UTM device, but communication is not encrypted within the LAN. Of course, it is possible to introduce communication encryption at the LAN level (e.g. MACSec mechanism), but it is redundant in relation to the applications discussed in the article.

\section{SUMMARY}

A modern solution for additive manufacturing of products from polymeric materials increasingly requires the use of network systems that allow remote control and monitoring of the manufacturing process selected stages.

The presented architecture elements were built in the rapid prototyping laboratory of Rzeszów University of Technology in order to confirm key functionalities and identify the limitations of the security architecture. The proposed security architecture is part of the tasks assigned to the implementation at the "RP processing stage" (see Fig. 4) in the proposed model. Tests in the lab implemented in cooperation with the socio-economic environment of Rzeszów University of Technology allowed to draw the following conclusions:

The implementation of the proposed architecture in the production environment can be performed based on available network protocols without the need to create additional dedicated software or protocol solutions;

After the architecture was implemented, a number of penetration tests from the Intranet and Extranet networks were performed, which did not show any vulnerabilities in the case of the architecture as a whole, despite the fact that the printers used had such vulnerabilities;

During the tests, the need to develop an application working in the cloud was identified, which would allow to integrate $3 \mathrm{D}$ printers made available using various techniques in the form of one coherent management system allowing (for) the implementation of tariff mechanisms for non-homogeneous resources from the ownership point of view.

The authors hope that the solutions presented in the article will prove helpful for companies and institutions related to the 3D printing industry and will positively influence their decisions on development towards digitization of production processes.

\section{REFERENCES}

[1] Haleem A., Javaid M.: Journal of Industrial Integration and Management 2019, 4(4), 1930001. https://doi.org/10.1142/S2424862219300011

[2] Horst D. J., Duvoisin CH. A., Vieira R. de A.: International Journal of Engineering and Technical Research 2018, 8(8), 3.

[3] Chong S., Pan G.-T., Chin J. et al.: Sustainability 2018, 10, 3960. https://doi.org/10.3390/su10113960

[4] Demirbağ K. S., Yildirim N.: Conference Engineering and Technology Management Summit At, Istanbul, Turkey 2018, 272.

[5] Patalas-Maliszewska J., Topczak M.: Advances in Production Engineering \& Management 2021, 16(1), 125. https://doi.org/10.14743/apem2021.1.389

[6] Schwab K: "The Fourth Industrial Revolution", Random House Lcc Us, USA 2016.

[7] Woźniak J., Budzik G., Przeszłowski Ł. et al.: Management and Production Engineering Review 2021, 12(2), 98. https://doi.org/10.24425/MPER.2021.137682

[8] Oztemel E., Gursev S.: Journal of Intelligent Manufacturing 2020, 31(4), 127. https://doi.org/10.1007/s10845-018-1433-8

[9] Paszkiewicz A., Bolanowski M., Budzik G. et al.: Processes 2020, 8, 1019. https://doi.org/10.3390/pr8091019

[10] Siemiński P., Budzik G.: „Techniki przyrostowe. Druk 3D. Drukarki 3D", Oficyna Wydawnicza PW, Warszawa 2015.

[11] www.octoprint.org (access date 08.05.2021)

[12] Śliwa R. E., Budzik G., Bernaczek J., Dziubek T.: Journal of KONES Powertrain and Transport 2011, 18(3), 439.

[13] Rokicki P., Budzik G., Kubiak, K. et al.: Aircraft Engineering and Aerospace Technology 2016, 88(3), 374. https://doi.org/10.1108/AEAT-01-2015-0018

[14] Magerramova L., Vasilyev B. Kinzburskiy V.: ASME Turbo Expo 2016: Turbomachinery Technical Conference and Exposition, Seoul, South Korea 2016. https://doi.org/10.1115/GT2016-56084

[15] Elakkad A.S.: International Journal of Engineering Research \& Technology 2019, 8(11), 248. http://dx.doi.org/10.17577/IJERTV8IS110122 
[16] Leal R., Barreiros F. M., Alves L. et al.: International Journal of Advanced Manufacturing Technology 2017, 92, 1671. https://doi.org/10.1007/s00170-017-0239-8

[17] Frandsen C. S., Nielsen M. M., Chaudhuri A. et al.: International Journal of Production Research 2019, 58(4), 970. https://doi.org/10.1080/00207543.2019.1605226

[18] Budzik G., Magniszewski M., Przeszłowski Ł. et al.: Polimery 2018, 63(11-12), 830. https://doi.org/10.14314/polimery.2018.11.13

[19] Lim J.H., Zhang X., Ting G.H.A. et al.: Journal of Building Engineering 2021, 39, 102221. https://doi.org/10.1016/j.jobe.2021.102221

[20] Marchment T., Sanjayan J.: Automation in Construction 2021, 127, 103694. https://doi.org/10.1016/j.autcon.2021.103694

[21] Hossain M.A., Zhumabekova A., Paul S.C. et al.: Sustainability 2020, 12, 8492. https://doi.org/10.3390/su12208492

[22] Salmi M.: Materials 2021, 14, 191. https://doi.org/10.3390/ma14010191

[23] Turek P., Budzik G., Przeszłowski Ł.: Polymers 2020, 12, 2444. https://doi.org/10.3390/polym12112444

[24] Okolie O., Stachurek I., Kandasubramanian B. et al.: Polymers 2020, 12, 2682. https://doi.org/10.3390/polym12112682

[25] Ugur M. D., Gharehpapagh B., Yaman U. et al.: Procedia Manufacturing 2017, 11, 545. https://doi.org/10.1016/j.promfg.2017.07.148

[26] Fiedler M.: 3D Printing and Additive Manufacturing 2015, 2(2), 85. https://doi.org/10.1089/3dp.2015.0011

[27] Paraskevoudis K., Karayannis P., Koumoulos E.P.: Processes 2020, 8, 1464. https://doi.org/10.3390/pr8111464
[28] Dodziuk H.: „DRUK 3D/AM. Zastosowania oraz skutki społeczne i gospodarcze", Wydawnictwo Naukowe PWN, Warszawa, 2019, ISBN/ISSN 9788301204655

[29] https://www.tiertime.com/up-studio/ (access date 08.05.2021)

[30] Martínez-Gutiérrez A., Díez-González J., FerreroGuillén R. et al.: Sensors 2021, 21, 3344. https://doi.org/10.3390/s21103344

[31] Ijaz M., Li G., Lin L. et al.: Electronics 2021, 10, 1077. https://doi.org/10.3390/electronics10091077

[32] Alzahrani B., Bahaitham H., Andejany M. et al.: Sustainability 2021, 13, 5169. https://doi.org/10.3390/su13095169

[33] Żywicki K., Zawadzki P., Hamrol A.: Advances in Information Systems and Technologies 2017, 571, 519. https://doi.org/10.1007/978-3-319-56541-5_53

[34] Budzik G., Woźniak J., Paszkiewicz A. et al.: Materials 2021, 14, 2202. https://doi.org/10.3390/ma14092202

[35] Zhong R.Y., Xu X., Klotz E. et al.: Engineering 2017, 3(5), 616. https://doi.org/10.1016/J.ENG.2017.05.015

[36] https://www.flexihub.com/ (access date 08.05.2021)

[37] https://www.net-usb.com/ (access date 08.05.2021)

[38] https://www.floow2.co/ (access date 08.05.2021)

[39] https://www.3dprinteros.com/ (access date 08.05.2021)

[40] https://www.raspberrypi.org/blog/how-to-set-up-octoprint-on-your-raspberry-pi/ (access date 08.05.2021)

[41] Ahmed K., Blech J.O., Gregory M.A. et al.: Journal of Sensor and Actuator Networks 2018, 7, 33. https://doi.org/10.3390/jsan7030033

[42] Fahim M., Sillitti A.: IEEE Access 2019, 7, 81664. https://doi.org/10.1109/ACCESS.2019.2921912

Recceived 18 VI 2021. 